ECONOMICS

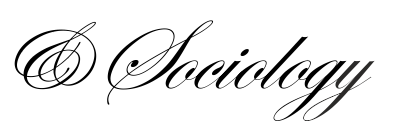

\title{
OPTIMAL PENSION SYSTEM: CASE STUDY
}

\author{
Alexander Nepp, \\ Ural Federal University, \\ Ekaterinburg, Russia, \\ E-mail:anepp@inbox.ru \\ Viola Larionova, \\ Ural Federal University, \\ Ekaterinburg, Russia, \\ E-mail:viola.larionova@gmail.com \\ Ostap Okhrin, \\ Technische Universität Dresden, \\ Dresden, Germany, \\ E-mail:ostap.okbrin@tu- \\ dresden.de
}

\author{
Alexander Sesekin, \\ Ural Federal University, \\ Ekaterinburg, Russia, \\ E-mail:sesekin@list.ru \\ Received: September, 2017 \\ 1st Revision: December, 2017 \\ Accepted: February, 2018 \\ DOI: $10.14254 / 2071-$ \\ 789X.2018/11-1/18 \\ JEL Classification: G23, \\ H55, H75
}

\begin{abstract}
Any reforms of pension systems inevitably involve their optimization, which is a challenging task since pension systems are dynamic, multidimensional and are affected by a variety of demographic, investment-related, and institutional random impact factors. The model described in this article aims at demonstrating the dependence of the target functions of pension systems on such factors. The current research sheds light on the influence of demographic parameters on funded and unfunded pension systems and shows the importance of institutional risks in both types of systems. The values of the state-regulated parameters for 2030 are specified, which allows us to maximize the key target functions: the replacement rate and pension benefits. Further, the results of empirical analysis of the impact factors affecting pension systems of OECD countries are described. The novelty of the paper lies in the analytical and quantitative methods used for the optimization of the pension system on the basis of the replacement rate
\end{abstract}

Keywords: pension systems; demographic risks; investment risks; institutional risks; reforms

\section{Introduction}

The optimization of pension systems is not a new question in economics. Demographic transformations necessitate constant adjustment and regular reformation of pension systems in almost all developed countries. All policy-makers, however, have to deal with the following question: what parameters should be set for the pension system and which type of system - funded or unfunded - should be prioritized. Modern economists have also studied this dilemma: various articles discuss the influence of factors on the operation of pension systems and on the economic environment.

The main risks to which pension systems are subject are demographic risks such as the increasing life expectancy, the growing number of retirees and the falling number of 
contributors to the pension system (Debon et al., 2008). To ensure the growth of the key parameters of pension systems, it is necessary to manage these risks efficiently.As far as the optimization of pension systems is concerned, we distinguish three major approaches in the existing studies. Studies adhering to the first approach Capretta et al. (2006) and Bosworth and Kent (2011) deal with self-adjusting pension systems. The problem, however, is that these studies do not take into account the dynamic nature of impact factors. The second approach strives to offer solutions tailored to the specific problems of pension systems (Holzmann, 2005). These studies focus on the probabilistic characteristics of certain factors while ignoring others (Holzmann, 2005). The third approach is the closest to our own as it uses OLG models to consider a pension system in a comprehensive, complex way. The studies adopting this approach take into account the dynamics of impact factors and aim to optimize the system by redistributing the resources between generations (Fudenberg and Tirole, 1991).

The primary goal of our research is to develop a pension system model which takes into account the joint impact of core factors with probabilistic characteristics. This is then used to determine the values of the state-regulated parameters for 2030, which allows us to maximize the objective functions. Thus, we will be able to determine the values of the pension system's control parameters to maximize the objective function.

The novelty of this paper lies in the fact that we are optimizing the pension system while not relying on the Pareto principal. In our understanding, optimality is a system with a combination of parameter values that maximizes the objective function of the system. Equally, we perform an optimization of the system with the reallocation of resources inside one generation, not between generations as occurs in OLG models. As objective functions of the pension system, we have chosen the value of pension benefits and the replacement rate, which are recommended by the International Labour Organization (ILO) as the main functions of pension provision. For a more detailed description of the abbreviations, please see the Appendix 2. The retirement age, the yield from the investment of pension assets in the storage system, the share of the mandatory funded pension in the pension system and the share of able-bodied citizens participating in the mandatory funded system are the regulation parameters in the proposed model. Parameters such as the share of the mandatory funded pension in the pension system and the share of able-bodied citizens participating in the mandatory funded system are considered institutional. The proposed model has the following limitations: the objective functions are maximized by redistributing resources inside one generation; the dynamics of the demographic factors are studied by analyzing changes in the demographic parameters over the past period in the given group of countries; and the dynamics of investment factors are studied by analyzing the changes in the investment factors over the past period in the given country. One more limitation concerns the institutional factors, which are considered only to a limited extent.

Despite its limitations, our model enables us to analyze the dynamic impact of investment and demographic factors, taking into account a limited number of institutional factors. This allows us to redistribute resources inside the generation to maximize the objective function of a pension system - the replacement rate.

This article is structured as follows. The model of the pension system and the process of modelling are described in Section 2. An overview of the characteristics of the Russian pension system is given in Section 3. Section 4 focuses on the optimization of the pension system's regulated parameters and provides further discussion of this problem. In Section 5, we offer our conclusions. 


\subsection{Literature review}

In 1995, the crisis in the pension system caused by changes in life expectancy and the retirement age led to a wave of forecasts predicting further destabilization of distribution pension systems if the increases in the retirement age failed to match the corresponding increases in life expectancy. According to the forecasts (James, 1995), more than $19 \%$ of the world population would be over 60 years old by 2030, compared to $9 \%$ in 1995 .

The demographic risks and their influence on pension systems have been thoroughly discussed Wills and Sherris (2010), which structures demographic risks, calculates them on the basis of the data provided by the National Statistical Service of Australia and concludes that there is a direct correlation between the successful management of pension funds and life insurance companies and the efficient management of demographic risks. The authors also propose that we take demographic risks into account in the computation of the costs of pension and life insurance products and also conduct securitization of demographic risks in the pension insurance sector. Issues of demographic risk management in pension and insurance sectors were discussed Debon et al. (2008), where the authors also propose applying a time series model for the analysis of demographic risks. The management of demographic risks in the pension and insurance institutions of South Korea in the gender context and in the context of long-term retirement has been studied Kwon (2008). It has been found that the increase in the time invested in caring for elderly people in the hospitals implies an increase in life expectancy, which in turn implies an increase in the demographic risks. The problems of actuarial calculations in the conditions of demographic risks are discussed Cossette et al. (2007), where a relation model of the prediction of mortality rates and its influence on the pension plan is proposed using Poisson regression analysis. Management of interest-rate and inflation risks in pension and insurance sectors is investigated Bikker and Vlaar (2007), where it is proposed to create reserve funds in pension institutions to minimize the impact of risks on their financial performance.

In terms of pension system optimization, the existing research can be divided into three major strands: those with a focus on the self-adjustment mechanisms of a pension system; those with optimal solutions for the specific problems of a pension system; and those dealing with a pension system as a whole. The research targeted at finding mechanisms for the self-adjustment of pension systems is usually based on balance models creating equilibrium of input and output in the system. In case of imbalance, the chosen control parameters are modified in order to bring the system into equilibrium. To minimize the impact of demographic risks, experts for the World Bank propose to restructure the pension system by infusing into the PAYG a funded component. While doing this, it is recommended not to replace the PAYG system completely with the funded one, but only part of it: the remaining part of the PAYG system should cover deficits in reallocations within and between generations, smoothing changes during a lifetime, etc. (Holzmann, 2005). The probable minimization of demographic risks in Latin America during the reformation of the PAYG system and the introduction of a multicomponent system that incorporates a funded part into the PAYG component has been discussed Fox and Palmer (2001). The social implications of this restructuring are discussed in the political documents of the World Bank (Schwarz and Demirguc-Kunt, 1999) and (Barrientos et al., 2003). As for the Russian system (Gurvich, 2010), provides significant research on inflation and interest-rate risks, where the replacement rate is considered the main criterion of the social development of pension systems. The paper seeks to prove that in order to maintain the replacement rate and the sustainability of a pension system, it is essential to increase the subsidies from the federal budget by one percentage point of the GDP every five years and to annually increase the rates of pension contributions by one percentage point. Relying on this analysis of the demographic indicators 
of OECD countries and the countries of emerging markets (using the author's own terminology), the author proposes to raise the retirement age to 62 for men and 60 for women. To prove this point, the average time span during which people receive pension benefits in the countries studied is highlighted. Similarly, Kudrin and Gurvich (2012) contends that the optimal reaction of the state to increasing average life expectancy should be to conduct constant adjustment of the retirement age while maintaining the proportion between the length of working life and the length of retirement. Such strategy provides the stability of the replacement rate and does not change the balance of relationships between the generations. A series of papers discuss annuitization and the functioning of pension institutions in the conditions of market risks. For example, Davidoff et al. (2005) analyzes the impact of behavioral patterns on the market prospects of pension insurance products. Another approach has been proposed Vidal-Melia et al., 2006), where the authors study and adopt the Value-atRisk (VaR) method to estimate the impact of macro-economic risks on the insurance and pension industries. The authors calculated the cost performance of macro-economic risks and $\mathrm{VaR}$ in order to determine their impact on the internal rate of return (IRR). This study holds a significant practical value for the insurance and pension industries since they act both as objects of investment and as objects of state regulation. The social aspect of this research is very important: the authors determined the impact of macro-economic risks on the replacement rate (RR), which is the main indicator recommended by the International Labour Organization to estimate the living standards of retired citizens. It is worth mentioning that Fehr (2000) discusses the optimization of private pension plans. Their results might be applied to social (obligatory) systems. By doing this, one needs to pay attention to the differences between systems. In particular, pension systems should take care of the financing of special categories of residents, such as the disabled. From the other side, social systems might have an additional source of financing from the government budget to cover different types of risks. More than half of OECD countries apply compensatory actions to minimize the exposure of pension systems to risks (D'Addio and Whitehouse, 2012; Bosworth and Kent, 2011). Such activities provide balance to the system by adjusting the retirement age (Capretta et al., 2006; Fudenberg. and Tirole, 1991), automatically balancing the size of contributions (Bosworth and Kent, 2011; Haberman and Zimbidis, 2002; Devolder et al., 2003) and optimizing pension systems by combining the optimal management of the investment assets of pension funds with the formation of an optimal payout policy (Haberman and Vigna, 2002; Devolder et al., 2003). The disadvantage of such an automatic adjustment mechanism is the absence of the complex, systemic approach: instead, it focuses only on the calibration of one or several parameters. Moreover, such mechanisms do not consider the volatilities of the individual factors of interest. Most interesting are works on the optimization of the pension system as one object with exogenous and regulatory factors of influence. The OLG model by Auerbach and Kotlikoff (1985) uses the notion of general equilibrium to maximize social welfare under certain restrictions. Bouchet et al. (2014) calibrates the aforementioned model and finds the optimal state of the pension system for the example of Luxembourg. In this case, the pension system was not considered to be autonomous, but rather as part of the global system interconnected by macroeconomic parameters. The model, however, considers the system as static, not allowing for dynamic changes. In particular, one cannot increase the retirement age or make possible changes in the relationship between unfunded and funded systems. The dynamics of the pension systems were considered by Godinez-Olivares et al. (2016), among others, which proposes approaches to the calibration of the optimal values of payments, retirement ages and indexation of the payments for the PAYG system, taking into account life expectancy, birth rate and salary increases. Billig and Menard (2013) took into account not only demographic but also four macroeconomic and institutional factors, namely the ratio of the funded to the unfunded parts in the obligatory pension system. Pantelous and 
Zimbidis (2008) proposes a stochastic model for the PAYG system, which has the form of a matrix for a set of pension plans. This is summarized in analytical equations that take into account the connection of target functions and parameters of influence. To summarize, the influence of specific factors on pension systems has received extensive coverage in the modern research literature. Many authors have put forward models for the optimization of pension systems, which demonstrates the importance of this problem. At the same time, the works cited above reveal an underexplored area since they consider pension systems either as stationary, without taking into account their constant change, or as dynamic but affected only by one specific kind of risk. Furthermore, these studies do not consider the probability factor of relevant impact factors. Studies addressing the optimization of pension plans as multifactor systems use the retirement age and/or investment returns as control parameters. We believe that a small number of control parameters significantly reduced their impact on pension systems. Therefore, it is essential to consider a wider range of control parameters. When solving the problem of the optimal pension system, the Pareto principal is widely used. Based on this, a system achieves its optimum when any further gains by any of the players are due to the losses of some of the other players (Fudenberg and Tirole, 1991). Based on this principle, the optimal reallocation of goods between generations while forming the pension system (Peters, 1991; Raut, 1992) and reforming the system of social benefits was proposed (Belan et al., 1998). Afterwards, the Pareto effectiveness was applied to solve similar problems of the reallocation of goods between generations using OLG-models (Wrede, 1999; Roberts, 2013). Based on the Pareto effectiveness, Breyer (1989) and Gyarfas and Marquardt (2001) proposed methods to look at the relationship between PAYG and a funded system, while Brunner (1996) discussed the necessity of moving from PAYG to a funded system, taking into account the effects of reallocations between generations. Using Pareto law, Kudrna and, Woodland (2011) and Fehr (2000) predicted the results of pension reforms in Australia and Germany, respectively. The primary goal of our research is to develop a pension system model which takes into account the joint impact of the core factors with probabilistic characteristics. It is then used to determine the values of state-regulated parameters for 2030, which allows us to maximize the objective functions. The novelty of this paper consists of the fact that we are optimizing the pension system without relying on the Pareto principle. In our understanding, optimality is a system with a combination of parameter values that maximizes the objective function of the system. We also perform an optimization of the system by reallocation of the resources inside one generation rather than between generations, as in OLG models. As objective functions of the pension system, we have chosen the value of pension benefits and the replacement rate, which are recommended by the International Labour Organization (ILO) as the main functions of pension provision (see www.ilo.org). The retirement age, the yield from the investment of pension assets in the storage system, the share of mandatory funded pensions in the pension system and the share of able-bodied citizens participating in the mandatory funded system are regulation parameters in the proposed model.

\subsection{Characteristics of the Russian Pension System: an Overview}

The pension system in Russia consists of mandatory and voluntary (additional) pension insurance. Voluntary pension insurance is based on a contract relationship between the insuring party, the insured person and non-state (private) pension funds. Contributions to voluntary pension schemes can be made by private individuals or legal entities. In the latter case, corporate pension schemes are set up. There are also mixed pension schemes, in which contributions can be made both by employees and their employers. Mandatory pension insurance is regulated by the law and is compulsory for the working population. Employers are liable to pay contributions for their employees to the pension fund at the rate of $22 \%$ of 
workers' taxable income. Out of $22 \%, 6 \%$ goes to the funded pension component while the other $16 \%$, to the unfunded component. The funded component consists of the funds accumulated on the individual accounts of insured persons. This money is invested and the investments return is allocated among the individual accounts.

Funds transferred to individual accounts are invested by specially authorized companies - non-state pension funds and managing companies. The returns on the investment are credited to individual pension accounts after the commission is charged by the pension company. The rules of investment are set by the regulator - the Central Bank of the Russian Federation - and prescribed by Federal Law № $111 .^{1}$ Russian pension funds have demonstrated negative investment inflation-adjusted returns from 2004 to $2015,-4.57 \%$ a year. $^{2}$ As we have shown previously, these results can be explained by the inefficient performance of the regulator (Pantelous and Zimbidis, 2008).

The unfunded component of the pension is based on a scoring system, which turns insured persons' revenues into scoring points. The value of a pension point is determined by the state, depending on the current economic situation. Funds from the unfunded pension component are used to provide pensions to present-day retirees. The retirement age in Russia is 60 for men and 55 for women. Some people can take early retirement due to hazardous or harmful work conditions which reduce life expectancy: for example, people working in the extreme north or beyond the Arctic circle are entitled to early retirement (45 for women and 50 for men). Furthermore, people of certain professions, such as pilots and flight attendants, are also entitled to early retirement schemes. Such preferential pensions are paid from the general fund, which puts a heavy burden on the compulsory pension system. In the framework of the PAYG system, pension payments from the federal budget are made to the specific categories of residents who do not receive rights to the types of pension payments listed above. To these categories belong age pensions, pensions to federal social workers and pensions for disabled residents. The average pension amount in the compulsory pension system in Russia was 10,900 roubles in 2014 , or 354.4 dollars with a replacement rate of $34 \%$. The average pension was 13,100 roubles, or 210.8 dollars, as of 23.10 .2016 (at the currency rate of 23.10.2016), while the replacement rate dropped to $32 \%$. By replacement rate, we mean not the classical definition given by convention N102 of the ILO, but the relationship of the average pension payment to the average salary. This is because the lack of statistical data for the Russian Federation requires the development of the model.

Another serious problem faced by the Russian pension system is demographic change. One of the key characteristics of the demographic risks faced by pension systems is the ratio of workers to retirees in the economy, which changed from 5.86 in 1990 to 5.11 in 2015 (OECD, 2013): according to different forecasts, it may fall to $2.8-4.2$ by $2030 .^{3}$ This process is accompanied by the increased life expectancy of people reaching the age of 60 . In 2015 , life expectancy for women aged 60 was 84.5 years and for men, 81.5 years. ${ }^{4}$

The demographic pressures, the decline in the working population and the increase in the number of retirees as well as considerable spending on preferential pensions require transfers from the federal budget to the budget of the Russian Pension Fund, the operator of

\footnotetext{
${ }^{1}$ Federal Law of 24.07.2002 N 111-FZ (amended as of 01.12.2014) 'On the Investment of Funds of the Funded Component of the Retirement Pension in the Russian Federation'.

${ }^{2}$ Data from the official website of the Russian Ministry of Finance: Access: www.minfin.ru. Last accessed: 23/12/2015.

${ }^{3}$ According to the optimistic and pessimistic forecasts of the Russian Statistics Committee. Source: The Official Web-Site of the Russian Statistics Committee (Roskomstat). Access mode:

http://www.gks.ru/wps/wcm/connect/rosstat_main/rosstat/ru/statistics/population/demography/\# last accessed date: 24.01.2018.

${ }^{4}$ The UN Forecast. Access mode: https://www.ssa.gov/oact/STATS/table4c6.html). Last accessed date: 1.11.2017.
} 
compulsory pension insurance. The amount of transfers in 2016 exceeded 1 trillion roubles, or 15.9 billion dollars. Despite the substantial subsidies, in 2016 the budget of the Russian Pension Fund still ran a deficit of 175 billion roubles, or 2.7 billion dollars. To cover this deficit, it was proposed to abandon the funded component and redirect funds to the unfunded component, that is, for payments to current retirees. Compulsory pension insurance in Russia comprises of funded and unfunded components. We demonstrate that the funded component should be preserved and provide empirical evidence that an increase in the replacement rate to the minimum recommended by the ILO by 0.4 times can be achieved by adjusting control parameters such as investment returns, the ratio of the funded and unfunded components in the contributions to compulsory pension insurance and the retirement age.

\section{Model of a Pension System. Methodological Approach}

When developing an optimal pension system, it is essential to define what is meant by optimality. In this article, optimality refers to finding the values of the pension systems' regulated parameters which in the current demographic, institutional and investment conditions will make it possible to maximize the system's objective functions. The objective functions in our setup are the pension benefits and the replacement rate (RR). As the restriction for our model under RR, we understand the relation of the working pension on aging to the average salary. As mentioned above, there are other types of pension systems in the Russian Federation: this type, however has the largest weight.

To determine the parameters of our pension system model, we summarized all the factors which were considered in the earlier works. These factors can be divided into the following groups:

- demographic parameters, which include the period of pension payments, the period of pension savings and the numbers of the working population and retired citizens;

- investment-based parameters, which include the rate of returns (as a decimal fraction) obtained from investing pension savings;

- institutional parameters, which include the share of the population participating in voluntary savings schemes and the share of expenses for funding preferential pensions in the total expenditure of the state pension fund.

Taken into account while constructing the model, these parameters can take values within specific ranges, which will be determined on the basis of the existing legal norms and the available statistical data.

The RR is understood as the replacement rate of a pension, which characterises the ratio of pensions from funded (cumulative) and unfunded (distributive) systems to the average salary $(\mathrm{S}): \mathrm{RR}=(\mathrm{PD}+\mathrm{PC}) / \mathrm{S}$. According to the Russian Pension Fund (see www.pfrf.ru), at present (as of 2014) the RR is RRi $=0.34$. Pension payments in the unfunded system can be represented as the fraction $(\mathrm{PD}=\mathrm{P} / \mathrm{n}$ ) of the sum of payments made into the unfunded pension system $(\mathrm{P})$ over the number of citizens who receive pension payments (n). Payments into the pension system are made from properly indexed salaries (S) in fraction (s) paid by the working population $(\mathrm{K})$ and are distributed in proportion $\mathrm{X}_{2}$ into the cumulative system and $\left(1-X_{2}\right)$ into the unfunded system. The portion $\mathrm{dm}$ is also used to finance the management of the system, while portion dp goes to pension payments that do not have an insurable character (pensions for specific working conditions). Thus, the payments into the unfunded systems are calculated as $\mathrm{PD}=1 / \mathrm{n} \cdot \mathrm{S} \cdot \mathrm{s} \cdot \mathrm{K} \cdot\left(1-\mathrm{X}_{2}\right)(1-\mathrm{dm}-\mathrm{dp})$. Payments from the funded pension system are made from the pension savings distributed over the average time of pension benefits $\left(\mathrm{t}_{\mathrm{v}}\right)$. Pension savings are formed from payments (s) and from properly indexed salaries (S), as well 
as from investments profits over $t_{n}$ from the payments with an average investment rate $X_{3}$. Payments from the funded system are given through $\mathrm{PC}=1 / \mathrm{t}_{\mathrm{v}} \cdot \mathrm{S} \cdot \mathrm{s} \cdot \mathrm{X}_{2} \cdot \sum_{q=1}^{t_{n}}\left(1+X_{3}\right)^{q}$, therefore

$$
R R=\frac{1}{t_{v}} \cdot s \cdot X_{2} \sum_{q=1}^{t_{n}}\left(\left(1+X_{3}\right)^{q}+s \cdot\left(1-X_{2}\right) \cdot \frac{K}{n} \cdot\left(1-d_{p}-d_{m}\right)\right)
$$

where the average salary $S$ has been cancelled out. Based on formula (1), we aim to maximise the replacement rate at year $2030\left(R R_{j}\right)$ relative to the replacement rate now (for the year 2014 , $R R_{i}$ ) via maximization of the $R R_{j} / R R_{i}$, taking into account that only fraction $X_{4}$ of the working population is involved in the funded system. Then, the RR in the forecast period (as of 2030) is determined by function (2) below, which is used to solve the problem of the maximization of $R R_{j}$ for 2030 and find the optimal parameters for a pension system:

$$
R R_{j}=R R_{i} X_{2} \frac{\sum_{q=1}^{t_{n_{j}}}\left(1+X_{3_{j}}\right)^{q}}{t_{v_{j}}} \frac{t_{v_{i}}}{\sum_{q=1}^{t_{n_{i}}\left(1+X_{3_{i}}\right)^{q}}} \cdot X_{4}+R R_{i}\left(1-X_{2}\right) \frac{K_{j}}{K_{i}} \frac{n_{i}}{n_{j}}\left(1-d_{m}-d_{p}\right),
$$

Let us recall once more all the variables: RRi is the RR for the year 2014, X2 is the weight of the funded pension component, $\mathrm{X} 3 \mathrm{k}$ is the returns from the investment of pension savings, tnk is the period of pension savings, tvk is the period of pension benefits, $\mathrm{Kk}$ is the working population, $n k$ is the retired population, where $k=i, j$ standing for years 2014 and 2030 respectively, $\mathrm{X} 4$ is the average share of the population participating in savings accumulation, $\mathrm{dm}$ are the shares of management costs in the expenditure of the mandatory pension system and dp are the shares of preferential uninsurable pensions in the expenditure of the mandatory pension system. Indices $\mathrm{m}$ and $\mathrm{f}$ will be introduced shortly to distinguish between the male and female fractions of the population.

According to the United Nations (see https://www.ssa.gov/oact/STATS/table4c6.html), in 2014 men's and women's life expectancy at age 60 years was 21.55 and 24.56 years respectively (we restrict ourselves to 60 years for both for men and women in order to use existing data). This results in the life expectancies $\mathrm{L}_{\mathrm{i}, \mathrm{m}}=60+21.55=81.55$ and $\mathrm{L}_{\mathrm{i}, \mathrm{f}}=60+$ $24.56=84.56$ years for men and women. Using a proportional increase of the prediction from $\mathrm{SSA}^{5}$, we obtain an increase by the factor 1.09 for life expectancy after reaching 60 years, which results in $\mathrm{L}_{\mathrm{j}, \mathrm{m}}=60+22.64=82.64$ and $\mathrm{L}_{\mathrm{j}, \mathrm{f}}=60+25.65=85.65$ years for men and women. The effective retirement age $\left(\mathrm{X}_{1, \mathrm{k}, \mathrm{f}}, \mathrm{X}_{1, \mathrm{k}, \mathrm{m}, \mathrm{k}}=\mathrm{i}, \mathrm{j}\right)$ typically depends on life expectancy and on the development level of the country: it is the age when the insured person is entitled to receiving his/her work pension. As for 2014, the effective retirement age was $\mathrm{X}_{1, \mathrm{~m}}=54.5$ and $\mathrm{X}_{1, \mathrm{f}}=52.6$ years for men and women respectively, where, as mentioned above, index $\mathrm{m}$ stands for male and $\mathrm{f}$ for female. For 2030, the prospective retirement age is assumed to take random values in the range $X_{1, j, m} \in\left(L_{i, m} ; L_{j, m}\right)$ for men and $X_{1, j, f} \in\left(L_{i, f} ; L_{j, f}\right)$ for women. Taking into consideration possible changes of the effective retirement ages $\left(\mathrm{X}_{1, \mathrm{j}}\right)$ in the future, the period of pension benefits in 2030 for men will be $t_{v j, m}=82.64-X_{1, j, m}$ years; for women, it will be $t_{v j, f}=85.65-X_{1, j, f}$ years.

The period of pension savings $\left(t_{n k}, k=i, j\right)$ is the period when regular contributions are made to funded pension systems, thus its length is computed as the difference between the effective retirement age and the age of entry into working life (we use the average value 24.4 years for 2014), namely $t_{n k}=X_{1, k}-24.4$. Thus, for 2014 pension savings periods were

\footnotetext{
${ }^{5}$ United Nations, Department of Economic and Social Affairs, Population Division (2017). World Population Prospects: The 2017 Revision, DVD Edition.
} 
$\mathrm{t}_{\mathrm{ni}, \mathrm{m}}=60-24.4=35.6$ and $\mathrm{t}_{\mathrm{ni}, \mathrm{f}}=55-24.4=30.6$ years for men and women respectively. The predicted values of the period of pension savings are computed in the same manner, by using future effective retirement age $\mathrm{X}_{1, \mathrm{j}}$.

The working population $\left(\mathrm{K}_{\mathrm{k}}, \mathrm{k}=\mathrm{i}, \mathrm{j}\right)$ consists of employed citizens who can make insurance payments into the pension system. In 2014, the working population was $\mathrm{K}_{\mathrm{i}}=86106$ citizens. According to the pessimistic forecast of the Federal Public Statistics Service (FPSS), the working population as of 2030 will be $K_{j, p}=73106$, while according to its optimistic forecast, it will be $K_{j, o}=80106$ citizens. The number of retired citizens $\left(n_{k}, k=i, j\right)$ in the current setup corresponds to the number of receivers of the unfunded component of pensions. At present, the number of retired citizens is $n_{i}=32106$ citizens. According to the pessimistic forecast of the FPSS, the number of pensioners in 2030 will be $n_{j, p}=36106$ while according to its optimistic forecast, it will be $\mathrm{n}_{\mathrm{j}, \mathrm{o}}=41106$ citizens.

The share of the general expenses of the Russian Pension Fund (RPF) is an indicator which characterizes institutional risks, that is, expenses related to the institutional system of pension fund regulation. These expenses are comprised of the share of management expenses ( $d_{m}$, the ratio of management expenses to the sum of all the RPF's expenses) and the share of preferential uninsurable pensions ( $d_{p}$, the ratio of the sum of preferential pensions (all pensions, except for unfunded, funded and basic) to the sum of all RPF's expenses). The calculations were made on the basis of the budget of the Pension Fund of the Russian Federation as of 2014 (see the Russian Federal Law No 385-FZ of 01.12.2014 "On the Budget of the Pension Fund of the Russian Federation for 2014 and for the Years under Planning 2015 and 2016"), with the share of general expenses $d_{m}+d_{p}=0.0247$.

For a more detailed description of the variable, please see the Appendix 1.

The variables that can be regulated by the state are called institutional variables (parameters). They can be used to maximize the objective functions, pension payments and the RR. Such variables include the effective retirement age $\left(X_{1}\right)$; the weight of the funded pension component $\left(X_{2}\right)$; investment returns from pension savings in the future $\left(X_{3}\right)$; and the average share of the population taking part in the funded pension system $\left(X_{4}\right)$.

Investment returns $\left(X_{3 k}, k=i, j\right)$ are the real (exceeding inflation) returns obtained from investing the funded pension component. The current investment returns $\left(\mathrm{X}_{3 \mathrm{i}}\right)$ are the average returns of all management companies in the period between 2004 and 2014, which were $\mathrm{X}_{3 \mathrm{i}}=-0.004$ per annum (Nepp, 2013, see Graph 2). Investment returns in the future $\left(\mathbf{X}_{3 \mathbf{j}}\right)$ are the forecast returns from management of the funded pension component for 2030. To find the investment returns in the future, we use the results of the modelled investment portfolio, which has demonstrated investment returns in the amount of $10.7 \%$ if institutional barriers are removed. We have taken the long-term level of inflation as $5.83 \%$. Thus, the real investment returns of this investment portfolio were set at the rate of $\mathbf{X}_{3 \mathbf{j}}=0.0487$ (Nepp, 2013). In our model of a pension system with maximized pension benefits and RR, the investment returns for 2030 can take any values in the range of $X_{3 \mathbf{j}} \in(-1 \% ; 0.38 \%)$. The weight of the funded pension component is defined as $X_{2} \in(0 ; 1)$, where for $X_{2}=0$ no contributions are paid and for $X_{2}=1$ there is no distribution pension, namely $100 \%$ of contributions go to the funded pension system.

The average share of the population participating in the funded pension system $\left(X_{4} \in(0,1)\right)$ is the population covered by the funded pension system. For $X_{4}=0$ nobody participates in funded pension systems and for $X_{4}=1100 \%$ of the population participate in funded pension systems.

Thus, simplifying the sums via geometric progression and denoting 


$$
\begin{array}{r}
A=R R_{i} \frac{t_{v_{i} X_{3_{i}}}}{\left(1+X_{3_{i}}\right)\left\{\left(1+X_{3_{i}}\right)^{t_{n_{i}-1}}\right.}, \\
B=R R_{i} \frac{K_{i}}{K_{j}} \frac{n_{j}}{n_{i}}\left(1-d_{m}-d_{p}\right) \\
F\left(X_{1}, X_{3}\right)=\frac{\left(1+X_{3}\right)\left\{\left(1+X_{3}\right)^{X_{1}-24,4}-1\right\}}{X_{3}\left(L_{j}-X_{1}\right)},
\end{array}
$$

formula (2) is thus simplified to

$$
R R_{j}\left(X_{1 j}, X_{2 j}, X_{3 j}, X_{4 j}\right)=X_{2 j}\left\{A \cdot X_{4 j} \cdot F\left(X_{1 j}, X_{3 j}\right)-B\right\}+B,
$$

where the constants $A$ and $B$ are computed according to the systems's fixed parameters, and therefore

$$
\begin{gathered}
A_{m}=0.34 \frac{(81.55-54.5)(-0.004)}{(1-0.004)\left\{(1-0.004)^{(54.5-24.4)}-1\right\}}=0.3239, \quad A_{f}=0.34 \frac{(84.56-52.6)(-0.004)}{0.996\left\{0.996^{(52.5-24.4)}-1\right\}}=0.4092 \\
B_{p}=0.34 \frac{86 \cdot 10^{6}}{73 \cdot 10^{6}} \frac{36 \cdot 10^{6}}{32 \cdot 10^{6}}(1-0.0247)=0.4394862 \text { and } B_{o}=0.34 \frac{86 \cdot 10^{6}}{80 \cdot 10^{6}} \frac{41 \cdot 10^{6}}{32 \cdot 10^{6}}(1-0.0247)=0.4567299
\end{gathered}
$$

To sum up, function (4) depends on four variables: $X_{1}$, the effective retirement age in the future; $\mathrm{X}_{2}$, the weight of the funded component in the future; $\mathrm{X}_{3}$, the investment returns in the future; and $\mathrm{X}_{4}$, the average share of people participating in the funded component in the future. As can be seen from (4), the dependence of the resulting function of variables $\mathrm{X}_{2}$ and $\mathrm{X}_{4}$, characterizing the volume of the funded component of the pension system, is linear while the impact of the investment returns and the effective retirement age is described by internal function $\mathrm{F}\left(\mathrm{X}_{1}, \mathrm{X}_{3}\right)$.

Let us study (3) in the range of possible values of variables $X_{1 j}$ and $X_{3 j}$. The maximum of $R R_{j}$ is reached if the values of internal function $F\left(X_{1 j}, X_{3 j}\right)$ are positive, which determines the analyzed range of variable $X_{1}$, as directly implied from (3) and (4):

$$
R R_{j} \rightarrow \max , \text { for } F\left(X_{1 j}, X_{3 j}\right)>0, \text { if } X_{1 i}<X_{1 j}<L_{j}
$$

According to (3) and (4), the value of the function grows exponentially, with effective retirement age $X_{1}$ approaching a value equal to life expectancy at the age of 60 years $L_{j}$ in the forecasted period. It means that $R R$ in the future $\left(R R_{j}\right)$ can be maximized (increased) primarily through increasing the effective retirement age. Importantly, the effective retirement age in the future must not exceed the average life expectancy at 60 years $L_{j}$ (for men $\mathrm{L}_{\mathrm{j}, \mathrm{m}}=$ 82.64 and for women $\mathrm{L}_{\mathrm{j}, \mathrm{f}}=85.65$ years).

A change of effective retirement age $X_{1 j}$ within the given range $\left[X_{1 i}\right.$; $\left.L_{j}\right]$ will affect $\mathrm{RR}_{\mathrm{j}}$ in the following way:

$$
\left.\begin{array}{c}
X_{1_{i}}<X_{1_{j}}<L_{j} ; \\
X_{1_{j}} \rightarrow L_{j}
\end{array}\right\}=>F\left(X_{1_{j}}, X_{3_{j}}\right) \rightarrow \infty=>R R_{j} \rightarrow \infty
$$

This means that if we raise effective retirement age $X_{1 j}$ within the range $\left[X_{1 i} ; L_{j}\right]$, function $F\left(X_{1 j}, X_{3 j}\right)$ will grow, which will lead to an increase in $R R_{j}$. In the extreme case, with $X_{1 j}$ approaching $L_{j}$, function $F\left(X_{1 j}, X_{3 j}\right)$ will tend to infinity and, consequently, target function $\mathrm{RR}_{\mathrm{j}}$ will blow up. 
Let us analyze the values of $\mathrm{X}_{1 \mathrm{j}}$ in function (3), for which the target function (4) will be minimal. As is seen from (3), function $F\left(X_{1 j}, X_{3 j}\right)$ has an unremovable discontinuity of the second type at the point $\mathrm{X}_{1 \mathrm{j}}=\mathrm{L}_{\mathrm{j}}$, when the effective retirement age equals the average life expectancy at 60 years $L_{j}$ in the forecasted period. When $\mathrm{X}_{1 j}$ exceeds the average life expectancy, function $F\left(X_{1 j}, X_{3 j}\right)$ became negative, which results in a reduction in the target function. This range of values is not discussed here because it is senseless from an economic point of view. The model under consideration is limited by condition $\mathrm{X}_{1}<\mathrm{L}_{\mathrm{j}}$.

On the other hand, if the future effective retirement age $X_{1 j}$ goes below the current level (54.5 for men and 52.6 for women) and reaches the level of entry into working life (24.4), this will lead to a fall in function $F\left(X_{1 j}, X_{3 j}\right)$, which, in turn, will lead to a dramatic decrease in $\mathrm{RR}_{\mathrm{j}}$ :

$$
\left.\begin{array}{c}
X_{1_{J}}<L_{J} ; \\
X_{1_{j}} \rightarrow 24.4 ; \\
X_{1_{j}}>24.4
\end{array}\right\} \Rightarrow F\left(X_{1_{j}}, X_{3_{j}}\right) \min =>R R_{j} \rightarrow \min
$$

Let us focus on the dependence of function $F\left(X_{1 j}, X_{3 j}\right)$ on variable $X_{3 j}$, which corresponds to the returns from investments of pension savings in the forecast period. As can be seen from (3) and (4), the function rises within the whole range of values of investment returns and has an unremovable discontinuity of the first kind at the point of zero returns.

$$
X_{1 j}=L_{j} \Rightarrow F\left(X_{1 j}, X_{3 j}\right)=\infty \Rightarrow R R j=\infty \text {. }
$$

The analysis shows that the higher the effective retirement age, the stronger the function's dependence on investment returns. This has a positive effect on the target function since an increase in investment returns leads to an increase in RR. Therefore:

$$
\begin{aligned}
& X_{3_{j}} \uparrow=>F\left(X_{1_{j}}, X_{3_{j}}\right) \rightarrow \infty=>R R_{j} \rightarrow \infty \\
& X_{1_{j}}<L_{j} \\
& \left.\begin{array}{l}
X_{3_{j}} \rightarrow 0 \\
X_{3_{j}} \geq 0
\end{array}\right\}=>F\left(X_{1_{j}}, X_{3_{j}}\right) \rightarrow \infty=>R R_{j} \rightarrow \infty
\end{aligned}
$$

This can be simply seen from the fact that $\partial \mathrm{F}\left(\mathrm{x}_{1}, \mathrm{x}_{3}\right) / \partial \mathrm{x}_{3}=\left(1+\mathrm{x}_{3}\right)^{\mathrm{x}^{1-25.4}}\left\{\mathrm{x}_{1}-24.4+\right.$ $\left.\left(\mathrm{x}_{1}-25.4\right) / \mathrm{x}_{3}\right\}$, which is obviously positive, since all the constituents are positive. Considering expressions (3) and (4) investigated how function $F\left(X_{1 j}, X_{3 j}\right)$ and $R R_{j}$ depend on the two variables (the effective retirement age $\left(X_{1 j}\right)$ and the investment returns of the funded pension component $\left(\mathrm{X}_{3 \mathrm{j}}\right)$ ), let us discuss how the proportion of the population participating in the funded pension system, $\mathrm{X}_{4 \mathrm{j}}$, affects the target function and find the range of values of this variable which make the target function rise. Expression (4) shows that RR can be maximized if we get a positive value of the multiplier in curly brackets of (4):

$$
\left\{\mathrm{A} \cdot \mathrm{X} 4 \mathrm{j} \cdot \mathrm{F}\left(\mathrm{X}_{1 \mathrm{j}}, \mathrm{X}_{3 \mathrm{j}}\right)-\mathrm{B}\right\}>0 \text { and } \mathrm{X} 2 \rightarrow 1=>\mathrm{RRj} \rightarrow \infty .
$$

As shown above, function $F\left(X_{1 j}, X_{3 j}\right)$ is positive for all values of $X_{1 j}$ and $X_{3 j}$ in the specified ranges. Constants $\mathrm{A}$ and $\mathrm{B}$ are also positive. Therefore, to maximize the target function the following inequality should be satisfied: 


$$
F\left(X_{1_{j}}, X_{3_{j}}\right) \cdot X_{4_{j}}>\frac{B}{A}
$$

The relation of constants B/A calculated on the basis of the pension system's main indicators is equal to 1.4103 (optimistic forecast and male population) 1.1163 (optimistic forecast and female population), 1.3569 (pessimistic forecast and male population) and 1.0740 (pessimistic forecast and female population). Then the lower limit of the value range for variable $\mathrm{X}_{4 \mathrm{j}}$ can be calculated according as follows:

$$
X_{4_{j}}>X_{4_{j, m i n}}=\frac{B}{A \cdot F\left(X_{1_{j}}, X_{3_{j}}\right)},
$$

The share of citizens participating in the funded pension system must be above minimal value $\mathrm{X}_{4 \mathrm{j}, \mathrm{min}}$. In this case, $\mathrm{RR}$ will grow in proportion to $\mathrm{X}_{4 \mathrm{j}}$.

Graph 1 represents the dependence of minimal values of this share of citizens $\left(\mathrm{X}_{4 \mathrm{j}}, \mathrm{min}\right)$ on the effective retirement age $\left(\mathrm{X}_{1 \mathrm{j}}\right)$ and investment returns $\left(\mathrm{X}_{3 \mathrm{j}}\right)$ for the male population (the female population looks similar and is therefore omitted for the sake of space). It is evident that to maximize the target function we need a sufficiently high proportion of people participating in the funded pension system. For instance, at present men's effective retirement age is 54.5 years and the investment returns are around $X_{3}=$ $-0.5 \%$, which means that in order to increase RR it is necessary to attract over $65 \%$ of the population to participate in the funded pension system. Such a situation is unattainable because of the negative investment returns and the consequent erosion of pension savings. If the investment returns become positive, then the population share required to participate in the funded pension system will become smaller.

The weight of the funded pension component is undoubtedly one of the state's main tools to regulate the pension system. Expression (4) demonstrates that the target function is directly proportional to variable $\mathrm{X}_{2 \mathrm{j}}$, corresponding to this system parameter. However, if condition (9) is not met and the expression in curly brackets in (4) becomes negative, it is possible to reduce the negative impact of other variables on RR by assuming that the weight of the funded component equals zero, which means that it is not feasible to preserve the funded pension system in this case. 

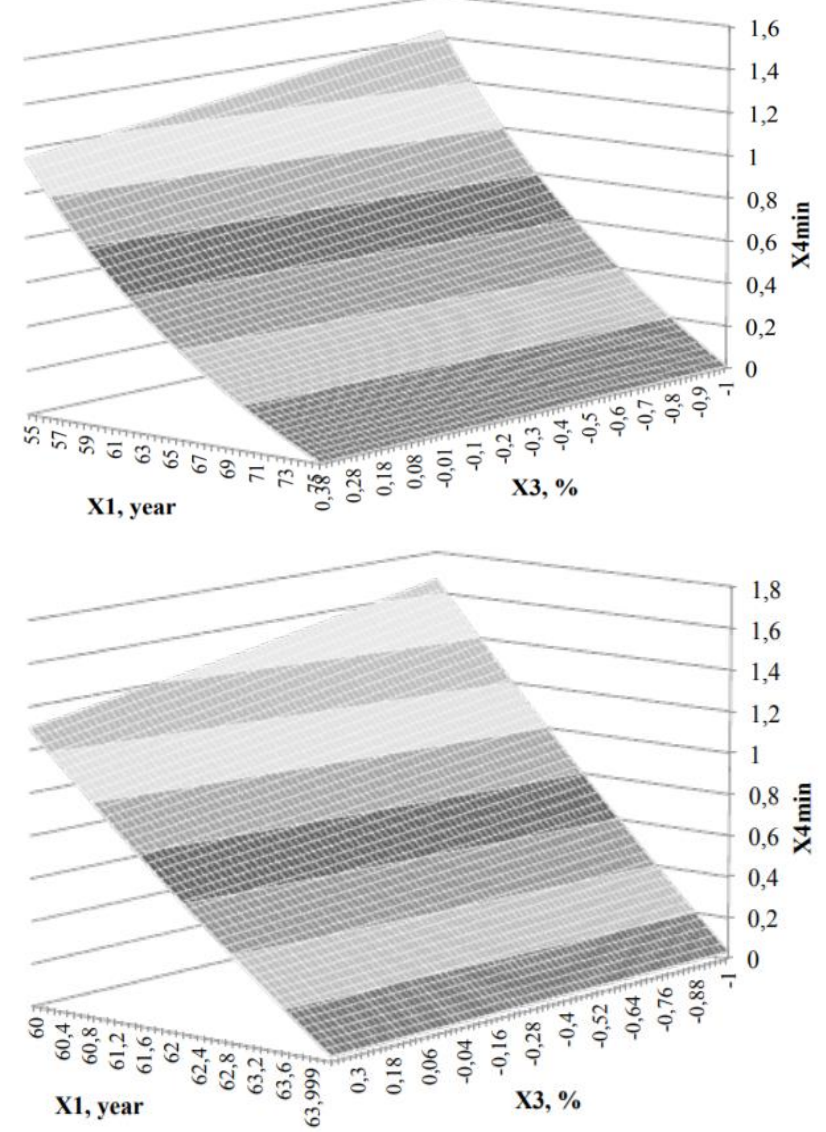

Graph 1. Dependence of the lower limit of the value range of variable $\mathrm{X}_{4 \mathrm{j}}$ (the share of citizens participating in the funded pension system) on the effective retirement age $\left(\mathrm{X}_{1 \mathrm{j}}\right)$ and investment returns $\left(\mathrm{X}_{3 \mathrm{j}}\right)$ for female (top) and male (bottom) populations

If the expression in curly brackets of (4) has a positive value, then an increase in the weight of the funded pension component will enhance the growth in the target function. Therefore

$$
R R_{j} \rightarrow \infty, \text { for }\left\{\begin{array}{c}
X_{2_{j}} \uparrow, X_{2_{j}}>0, X_{4_{j}} \geq \frac{B}{F\left(X_{1_{j}}, X_{3_{j}}\right) \cdot A} \\
X_{2_{j}}=0, \quad X_{4_{j}}<\frac{B}{F\left(X_{1_{j}}, X_{3_{j}}\right) \cdot A}
\end{array}\right.
$$

Thus, a pension system is a system of interconnected parameters, open both for internal and external impact. To achieve high values of the target function $(\mathrm{RRj})$, it is essential to meet a number of conditions and restrictions on the given parameters. Our analysis has shown that the growth of each separate parameter (effective retirement age, returns of pension savings investments, the share of the population participating in the funded pension system and the weight of the funded pension component) enhances the growth in RR. However, this is not only a criterion that serves as an indicator of the system's optimality but is also a combination of their values. For example, the feasibility of the funded pension component can be checked by condition (9), which contains three out of four given parameters and sets the share of citizens participating in the funded pension system with the specified investment 
returns and the effective retirement age. If the investment returns are negative and the funded pension system loses its participants, then this condition will not be met and the funded pension system will be rendered infeasible, which will result in the need to reconsider all the parameters.

Before we start discussing alternative methods of finding the parameters of the pension system's target functions, let us summarize the results of our analysis and describe the conditions which will allow us to maximize $\mathrm{RRj}$ as one of the core indicators of a pension system. According to expressions (4), (6), (8) and (9), an increase in the resulting function $(\mathrm{RRj})$ can be achieved the following ways:

1. By raising the legal retirement age. This might imply an increase in the effective retirement age or cancellation of early retirement for specific groups. This is an effective but extremely unpopular measure in pension system regulation;

2. By increasing returns from investments of pension savings, which is restricted by the regulating legal acts in the pension sphere;

3. By increasing the weight of the funded pension component. This measure will be effective only if the share of citizens participating in the funded pension system exceeds a certain threshold value, which can be calculated according to (10);

4. By increasing the share of people participating in the funded pension system, which is possible only if the returns from investments of pension savings are positive.

The summary of our results is demonstrated by the following expression:

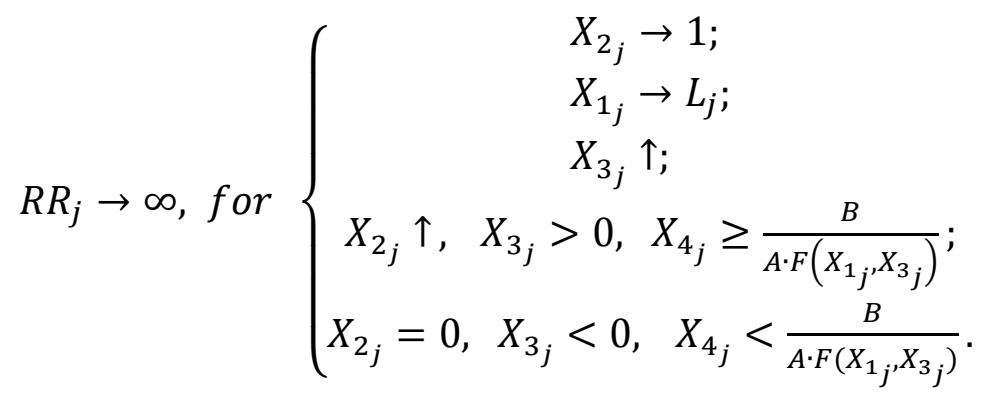

An important institutional conclusion which can be drawn from the analysis described above is the following: the point is not to eliminate the funded pension component but to enhance the institutional regulation, which would enable the government to attract more people to the funded pension system. This can be achieved by increasing the returns from investing pension savings and by the state's co-funding of the funded pension component.

The results presented in (12) cannot serve as a complete answer to the question of finding the optimal values for a pension system and of maximizing its RR. As we have already pointed out when discussing expression (4), this can be achieved by applying alternative methods, as we see in the next section.

\section{Discussion of the optimization of a pension system}

To develop a pension system and determine its optimal parameters, we make an assumption that the parameters in question are random variables which can take values in the range sets discussed in the previous section. At the same time, we know that variables take values in accordance with certain distribution laws that might be Gaussian, lognormal, gamma or chi- square. To get a feeling of the distribution, we have to analyze the statistical data on the investment returns and the effective retirement age. 
For the analysis of investment returns, we use the annual returns of 68 companies which managed investments of pension savings in the period between 2004 and 2014. After computing the average returns of pension savings for each of the 68 companies and adjusting the calculated values of the nominal investment returns to the annual average inflation of $5.46 \%$ in the given period (Official Website of the Federal Public Statistics Service of the Russian Federation. Access mode: www.gks.ru.), we computed the kernel density estimator (KDE) with the Gaussian kernel (with the bandwidth estimated via Silvermans' rule of thumb) of the investment returns in the 2004-2014 period (see Graph 2). Even a simple visual inspection implies that the current variable follows none of the standard distributions: different tests for Gaussian, $t$ and stable distributions were rejected on the high significance level. Therefore, for further analysis a nonparametric distribution function is used. Let us analyze the distribution of the effective retirement age. It is important to recall that the effective retirement age is not an independent random value, as it is determined by life expectancy at age 60 . We consider life expectancy at age 60 instead of life expectancy at the effective retirement age because of the existence of data. When analyzing the distribution of the effective retirement age, one needs to take into account the relation between the life expectancy and the retirement age and thus their fraction. This indicator is analyzed separately for men and women in nineteen OECD countries: Australia, Austria, Great Britain, Hungary, Germany, Italy, Canada, Luxembourg, Mexico, the Netherlands, Norway, Poland, Slovenia, the USA, the Czech Republic, France, Switzerland, Sweden and Japan. The data for the analysis of men's and women's retirement age are shown in Table 1. In Table 1 is Data for retirement age and life expectancy for pensioners. On the basis of the present tables, we find the distribution of life expectancy/retirement age, which we apply during modelling.

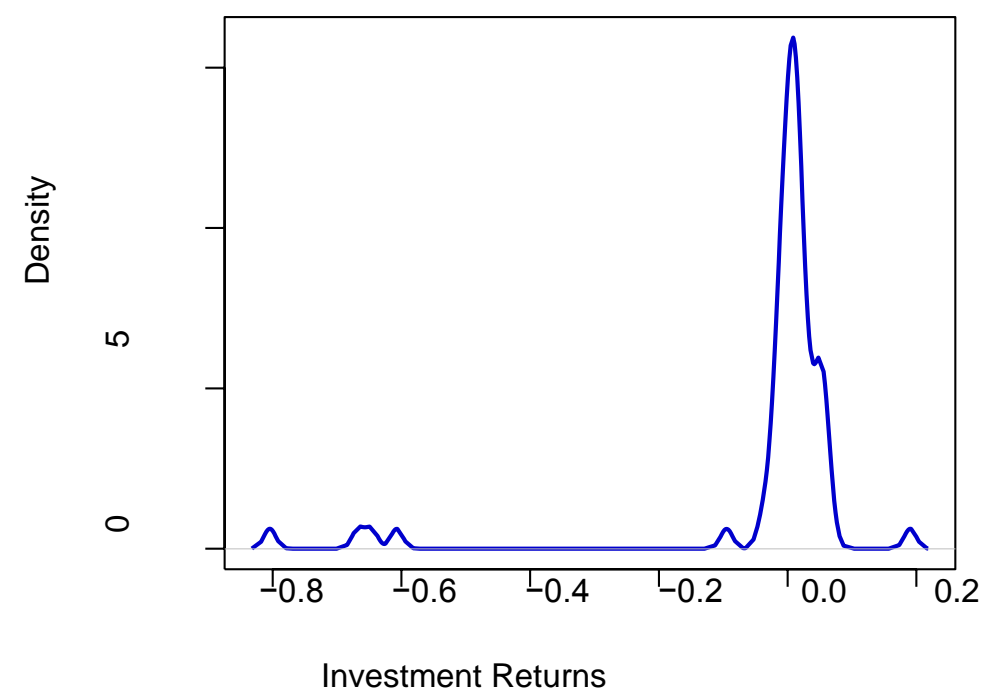

Graph 2. Probability density of the real returns from the investment of pension savings in the period between 2004 and 2014 
Table 1. Retirement age and the life expectancy for men and women in OECD countries

\begin{tabular}{lcccccc}
\hline Country & \multicolumn{2}{c}{ Eff. Ret. age } & \multicolumn{2}{c}{ Life exp. at 60 } & \multicolumn{2}{c}{ Life exp.at 60 } \\
\hline & menf.Ret.age & women & men & women & men & women \\
\hline Australia & 64.9 & 62.9 & 84.4 & 86.8 & 1.30 & 1.38 \\
\hline Austria & 61.9 & 59.4 & 82.2 & 85.9 & 1.33 & 1.45 \\
\hline Canada & 63.8 & 62.5 & 83.5 & 86.4 & 1.31 & 1.38 \\
\hline Czech Republic & 63.1 & 59.8 & 79.8 & 83.9 & 1.26 & 1.40 \\
\hline France & 59.7 & 60.0 & 83.5 & 87.7 & 1.40 & 1.46 \\
\hline Germany & 62.1 & 61.6 & 81.9 & 85.4 & 1.32 & 1.39 \\
\hline Hungary & 60.9 & 59.6 & 77.7 & 82.9 & 1.28 & 1.39 \\
\hline Italy & 61.1 & 60.5 & 83.3 & 86.6 & 1.36 & 1.43 \\
\hline Japan & 69.1 & 66.7 & 83.4 & 88.7 & 1.21 & 1.33 \\
\hline Luxembourg & 57.6 & 59.6 & 82.5 & 85.9 & 1.43 & 1.44 \\
\hline Mexico & 72.3 & 68.7 & 81.1 & 83.8 & 1.12 & 1.22 \\
\hline Netherlands & 63.6 & 62.3 & 82.6 & 85.7 & 1.30 & 1.37 \\
\hline Norway & 64.8 & 64.3 & 82.6 & 85.7 & 1.27 & 1.33 \\
\hline Poland & 62.3 & 60.2 & 89.2 & 84.0 & 1.43 & 1.40 \\
\hline Slovenia & 62.9 & 60.6 & 78.0 & 82.9 & 1.24 & 1.37 \\
\hline Sweden & 66.1 & 64.2 & 83.3 & 85.8 & 1.26 & 1.34 \\
\hline Switzerland & 66.1 & 63.9 & 83.9 & 87.0 & 1.27 & 1.36 \\
\hline United Kingdom & 63.7 & 63.2 & 82.7 & 85.3 & 1.30 & 1.35 \\
\hline United States & 65.0 & 65.0 & 82.1 & 85.0 & 1.26 & 1.31 \\
\hline
\end{tabular}

Source: authors' calculations based on data of OECD a Glance 2013: OECD and G20 Indicators, OECD Publishing. Access mode: http://dx.doi.org/10.1787/pension_glance-201314-en. last accessed date: 24.01.2014.

The KDE (with Gaussian kernel and the bandwidth estimated via Silvermans' rule of thumb) of women's (in red) and men's (in blue) life expectancy at 60 over the effective retirement age for OECD countries in 2010 is given in Graph 3. Both estimators have a slightly skewed distribution which rejects all the common symmetric distributions (like Gaussian, $t$, family, etc.). In the further study, we also use the empirical distribution for this variable. A comparative analysis of the ratio between men's and women's life expectancy at 60 to the effective retirement age has allowed us to come to a conclusion that is significant for the institutional regulation of the Russian pension system. 


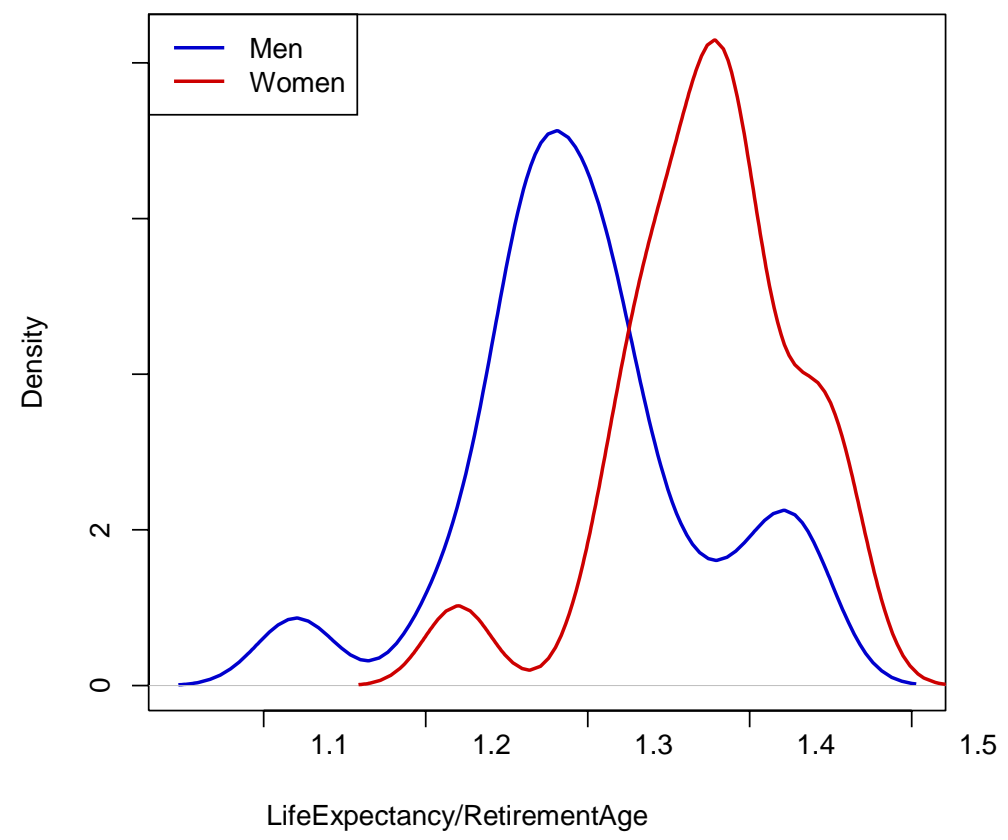

Graph 3. KDE of the ratio of women's (red) and men's (blue) life expectancy over retirement age for OECD countries in 2010

In accordance with the demographic forecast made by the Federal State Statistics Service, the ratio between life expectancy at 60 and effective retirement age is 1.5 and 1.61 for men and women respectively. In OECD countries, for men this range is $(1.1 ; 1.4)$; for women, $(1.2 ; 1.5)$. These results demonstrate that in Russia, taking into consideration men's and women's life expectancy at 60 , the effective retirement age is too low for men and women.

Unfortunately, we were unable to find enough statistical data on the other two indicators (the weight of the funded component in pension provision and the average share of citizens participating in the funded pension system), which prevented us from reaching any statistically significant conclusions. To the best of our knowledge, there is no recent research that addresses this problem. Therefore, when modelling the target function and specifying the optimal parameters of a pension system, we took them to be equal to 0.8 , which, in general, represents the actual situation.

The modelling of the optimal parameters of a pension system was done by mapping the bivariate distribution function of $\left(\mathrm{X}_{1 \mathrm{j}}, \mathrm{X}_{3 \mathrm{j}}\right)$ onto formula (4), thus highlighting the most probable values of RR for the future most probable values of the investment returns and effective retirement age. Next, we found the extremum of the function considering the probability distribution of the values of the variables and identified the optimal parameters.

The results of the objective function modelling $\left(R_{\mathrm{j}}\right)$ take into account the distribution of the variables, the effective retirement age $\left(\mathrm{X}_{1 \mathrm{j}}\right)$ and the investment returns $\left(\mathrm{X}_{3 \mathrm{j}}\right)$ (see Figure 4, upper panel for women and lower panel for men). The dependency between the two variables $X_{1 j}$ and $X_{3 j}$ is taken into account as their joint density has been computed via the bivariate kernel density estimator with the product Gaussian kernel: both bandwidths are estimated via Silvermans' rule of thumb. The weight of the funded component in the pension provision $\left(\mathrm{X}_{2 \mathrm{j}}\right)$ and the share of people participating in the funded pension system $\left(\mathrm{X}_{4 \mathrm{j}}\right)$ were set at 0.8. In the figures, the areas of different probability of achieving the target function values are highlighted by the red and blue colors: the red color corresponds to the most probable values while the blue refers to the least probable ones. 
The discontinuity of the target function at the point where the investment returns are equal to zero can be explained by the singularity of function (4) at this point. When the investment returns $\left(X_{3 j}\right)$ are approaching zero, function $F\left(X_{1 j}, X_{3 j}\right)$ and, consequently, $R R_{j}$ tend to infinity:

$$
X_{3_{j}} \rightarrow 0=>F\left(X_{1_{j}}, X_{3_{j}}\right) \rightarrow \infty=>R R_{j} \rightarrow \infty .
$$

As is seen from the figures, the increase in the effective retirement age $\left(\mathrm{X}_{1 \mathrm{j}}\right)$ and the investment returns will also increase RR. Its minimal value for men is 0.2941 , with the investment returns $\left(\mathrm{X}_{3 \mathrm{j}}\right)$ being $-1 \%$ and the effective retirement age 54.5 years. For women, the minimal $\mathrm{RR}$ is equal to 0.2851 , with the investment returns being $-1 \%$ and effective retirement age 52.6 years. With the real investment returns set at $0.38 \%$ (which is historically the largest value observed) and the effective retirement age 76.5 years, RR will reach its maximum value, 98.6. For women, at effective retirement age 81.1 years and investment returns set at $0.38 \%$, RR will reach the maximum at 148.1 . This is logical, as the effective retirement age tends to the life expectancy at 60 and the size of pension payments and RR tend to infinity. Therefore, we took the life expectancy minus one month in order to be bounded from infinity and as the pensions are paid on a monthly basis. However, if investment returns are set to $0.38 \%$ and effective retirement age for men to 68.0 years and for women to 69.2 years, RR becomes 1.04. If RR reaches 1.04 (which means that pension benefits will exceed the person's level of wages before the retirement 1.04 times), then the insured person will find it much more profitable to retire rather than to continue working. Such a pension system will discourage people from working.

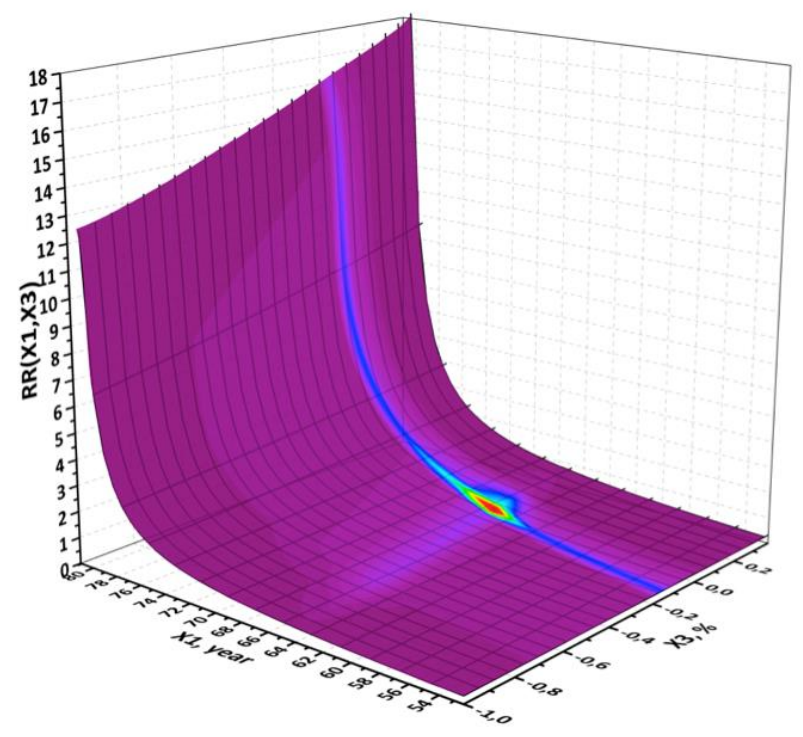




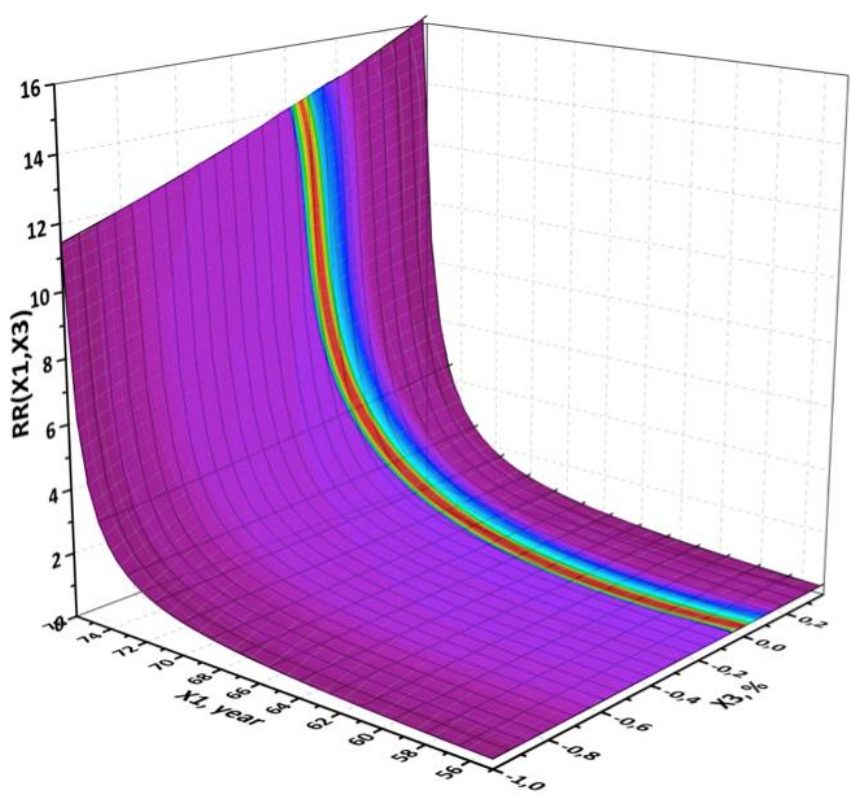

Graph 4. Dependence of RRj on the effective retirement age $\left(X_{1 j}\right)$ and investment returns $\left(X_{3 j}\right)$ for male (top) and female (bottom) population

Therefore, we believe that our primary goal to maximize the main parameters of the pension system by changing its parameters must be adjusted and stated as "finding the optimal indicators of the pension system by changing its parameters in such a way that they will not negatively affect the labour market". For the lowest optimal value of RR, we could use the ILO's recommendations for the minimal RR (0.4) and as the upper limit we could use the average value of RR in the mandatory pension insurance programs in OECD countries, 0.55 (www.ilo.stat). Thus, the task comes down to defining the region of the pension parameters which would keep $R R$ in the range of $R_{j} \in[0.4 ; 0.55]$. According to the upper panel of Graph 4 (results for men), RR in the allowable range can be achieved if $\mathrm{X}_{3 \mathrm{j}} \geq 0.12 \%$. The most probable values for effective retirement age, as we found earlier, are in the range between 60.5 and 64 years for men and 58 and 62 years for women (lower panel). However, if we decrease the effective retirement age in the most probable area we will decrease RR, which contradicts to our aim. If we also consider the most probable values of RR, the optimal parameters (investment returns and the effective retirement age) will be as follows:

$$
R R_{j} \in[0.40 ; 0.55] \text { for } X_{1_{j}} \in[60.5 ; 64] \text { and } X_{3_{j}} \in[0.12 \% ; 0.18 \%]
$$

This means that we are most likely to achieve the RR recommended by the ILO in the range between 0.4 and 0.54 by increasing the average effective retirement age $\mathrm{X}_{1 \mathrm{j}}$ to 60.5 64 years and the real investment returns to $0.12-0.18 \%$. For the women, the replacement coefficient lying in the same range of $\mathrm{RR}_{\mathrm{j}} \in[0.4 ; 0.55]$ recommended by ILO can be reached with the investment returns being in the range of $X_{3 j} \in[0.12 \% ; 0.18 \%]$ and the retirement age being $X_{1 j} \in[58 ; 62]$. Thus by conducting an intersection of the intervals, we obtain that

$$
R R_{j} \in[0.40 ; 0.55] \text { for } X_{1_{j}} \in[58 ; 62] \text { and } X_{3_{j}} \in[0.12 \% ; 0.18 \%]
$$

Thus RR is exactly on the lower boundary of the interval suggested by the ILO. 
The results we received agree with the World Bank's recommendations that in a period characterized by declining birth rates and growing life expectancy, governments should give priority to the funded pension system rather than to the traditional distribution system while simultaneously raising the retirement age (Schwarz and Demirguc-Kunt, 1999). Our results specify the share of the funded component in pension contributions and the corresponding increase in the retirement age necessary to optimize the pension system. We believe that if the negative effects of state regulation are eliminated and the funded component is introduced, it will be possible to minimize the inevitable rise in retirement age. For men, if the investment yields are [0.12;0.18], it will be sufficient to increase the retirement age to $[60.5 ; 64]$; for women, to $[58 ; 62]$.

\section{Conclusion}

Pension systems should be considered as non-stationary economic systems, which have parameters with varying probability. To take into account their dynamic impact on pension systems, we should consider the following groups of parameters: firstly, demographic parameters (the period of paying pension benefits, the period of pension savings, the numbers of the working population and retired citizens); secondly, investment parameters (the rate of investment returns obtained from investing pension savings, in decimal fractions); and thirdly, institutional parameters (the share of the population participating in voluntary funded pension programs and the share of expenditure on funding preferential pensions in the total expenditure of the state pension fund).

Considering men's and women's life expectancy at 60 in Russia, the effective retirement age is set too low if compared to the average ratio life expectancy at 60 to the effective retirement age in OECD countries. The living standards for the retired population should be maintained at the average level of OECD countries determined by the ratio of the life expectancy at 60 to the effective retirement age, that is, the relative retirement period. In order to achieve these standards, women's and men's effective retirement age should be raised considerably. The most optimal effective retirement age for men would be between 60.5 and 64 years, while for women between 58 and 62 years.

The most probable values of the investment returns (without inflation) from pension savings invested in assets, based on the empirical distribution of the returns over 2004-2014, are in the interval $(0.12 \% ; 0.18 \%)$. Thus, even a slight increase in the investment returns will imply an increase in $\mathrm{RR}_{\mathrm{j}}$. In the case of negative investment returns on pension savings and with a small proportion of the population participating in the funded pension system, it is counterproductive to support or create a funded pension system. In conditions of wage stagnation, the growth of RR and pension benefits can be achieved only by increasing the retirement age. By the increase of the effective retirement age to the average life expectancy at 60 , RR tends towards infinity. RR for men can be raised to be in the interval between 0.4 and 0.55 (recommended by ILO) by increasing the effective retirement age to be in the interval between 60.5 and 64 years or by increasing the investment returns to $0.12-0.18 \%$. For women, the retirement age should be between 58 and 62 years or the investment returns should not be below $0.12 \%$.

If the investment returns are negative and the share of people participating in the funded pension component is small, it is better to apply institutional regulation, which would increase the returns and make this part of the pension system more attractive for the population, rather than eliminate the funded pension component. 


\section{Acknowledgement}

We would like to express our deepest gratitude and appreciation to Prof. Oleg Nikonov (sadly deceased) (Ural Federal University) for his wise advice and assistance.

We would also like to thank our colleagues Ekaterina Purgina and Viktoria Polyakova (Ural Federal University) for their help and patience.

This research is supported by the Russian Science Foundation RSF Grant No 15-1810014 'Projection of optimal socio-economic systems in turbulent external and internal environments'.

\section{References}

Auerbach, A. J., Kotlikoff, L. J. (1985). Simulating alternative social security responses to the demographic transition. National Tax Journal, 38(2), 153-168.

Barrientos, A., Gorman, M., and Heslop, A. (2003). Old age poverty in developing countries: contributions and dependence in later life. World Development, 31(3), 555-570.

Belan, P., Michel, P., Pestieau, P. (1998). Pareto-improving social security reform. GENEVA Papers on Risk and Insurance Theory, 23(2), 119-125.

Bikker, J. A., Vlaar, P. J. (2007). Conditional indexation in defined benefit pension plans in the Netherlands. Geneva Papers on Risk and Insurance: Issues and Practice, 32(4), 494-515.

Billig, A., M'enard, J.-C. N. (2013). Actuarial balance sheets as a tool to assess the sustainability of social security pension systems. International Social Security Review, 66(2), 31-52.

Bosworth, B., Kent. W. (2011). Social Security on auto-pilot: international experience with automatic stabilizer mechanisms. Center for Retirement Research at Boston College, p. 46.

Bouchet, M., Marchiori, L., Pierrard, O. (2014). D'eficit, croissance et bien-^etre interg'en'erationnel: Comment r'eformer les pensions au Luxembourg? BCL working papers, 87, Central Bank of Luxembourg.

Breyer, F. (1989). On the intergenerational Pareto efficiency of pay-as-you-go financed pension systems. Journal of Institutional and Theoretical Economics, 145(4), 643-658.

Brunner, J. K. (1996). Transition from a pay-as-you-go to a fully funded pension system: The case of differing individuals and intragenerational fairness. Journal of Public Economics, 60(1), 131-146.

Capretta, V., Uustalu, T., Vene, V. (2006). Recursive coalgebras from comonads. Information and Computation, 204(4), 437-468.

Cossette, H., Delwarde, A., Denuit, M., Guillot, F., Marceau, E. T. (2007). Pension plan valuation and mortality projection: A case study with mortality data. North American Actuarial Journal, 11(2), 1-34.

D'Addio, A. C., Whitehouse, E. (2012). Towards financial sustainability of pensions systems: the role of automatic adjustment mechanisms in OCDE and EU countries. Bundesamt für Sozial, 8(12), 79 p.

Davidoff, T., Brown, J. R., Diamond, P. A. (2005). Annuities and individual welfare (Review). American Economic Review, 95(5), 1573-1590.

Debon, A., Montes, F., Puig, F. (2008). Modelling and forecasting mortality in Spain. European Journal of Operational Research, 189(3), 624-637.

Devolder, P., Princep, M. B., Fabian, I. D. (2003). Stochastic optimal control of annuity contracts. Insurance, Mathematics and Economics, 33(2), 227-238. 
Fehr, H. (2000). Pension reform during the demographic transition. Scandinavian Journal of Economics, 102(3), 419-443.

Fox, L., and Palmer, E. (2001). New approaches to multipillar pension systems: What in the world is going on? In: New ideas about old age security (eds.). Holzmann, R., and Stiglitz, J. E., pp. 90-132.

Fudenberg, D. and Tirole, J. (1991). Game theory. Cambridge, Massachusetts: MIT Press. pp. 18-23. ISBN 9780262061414

Godinez-Olivares, H., Boado-Penas, M. D. C., Pantelous, A. A. (2016). How to Finance Pensions: Optimal Strategies for Pay-as-You-Go Pension Systems. Journal of Forecasting, 35(1), 13-33.

Gurvich, E. (2010). Reform 2010: Resolved if long-term problems of the pension system. Journal of New Economic Association, 6, 98-119.

Gyarfas, G., Marquardt, M. (2001). Pareto improving transition from a pay-as-you-go to a fully funded pension system in a model of endogenous growth. Journal of Population Economics, 14(3), 445-453.

Haberman, S. and Vigna, E. (2002). Optimal investment strategies and risk measures in defined contribution pension schemes. Insurance: Mathematics and Economics, 31, 35-69.

Haberman, S., and Zimbidis, A. (2002). An investigation of the pay-as-you-go financing method using a contingency fund and optimal control techniques. North American Actuarial Journal, 6, 60-75.

Holzmann, R. (2005). Old-age income support in the 21st century: An international perspective on pension systems and reform. World Bank Publications, $229 \mathrm{p}$.

James, E. (1995). Averting the old age crisis. Ageing International, 22(2), 15-22.

Kudrna, G., Woodland, A. D. (2011). Implications of the 2009 age pension reform in Australia: a dynamic general equilibrium analysis. Economic Record, 87(277), 183-201.

Kudrin, A., Gurvich, E. (2012). The aging population and the threat of a budget crisis. Voprosy economici, 3, 52-79.

Kwon, S. (2008). Future of long-term care financing for the elderly in Korea. Journal of Aging and Social Policy, 20(1), 119-136.

Nepp, A. (2013). The role of demographic risks for unfunded pension systems. World Applied Sciences Journal, 27, 234-240.

OECD (2013), Tax treatment of pensions and pensioners, In: Pensions at a Glance 2013: OECD and G20 Indicators, OECD Publishing. Access mode http://dx.doi.org/10.1787/pension_glance-2013-14-en. last accessed date: 24.01.2014.

Pantelous, A., Zimbidis, A. (2008). Dynamic reforming of a quasi pay-as-you-go social security system within a discrete stochastic multidimensional framework using optimal control methods. Applicationes Mathematicae, 35, 121-144.

Peters, W. (1991). Public pensions in transition - An optimal policy path. Journal of Population Economics, 4(2), 155-175.

Raut, L. K. (1992). Effect of social security on fertility and savings: an overlapping generations model. Indian Economic Review, 27(1), 25-43.

Roberts, M. A. (2013). Pareto-improving pension reform through technological implementation. Scottish Journal of Political Economy, 60(3), 317-342.

Schwarz, A. M., and Demirguc-Kunt, A. (1999). Taking stock of pension reforms around the world. Social Protection, World Bank.

United Nations, Department of Economic and Social Affairs, Population Division (2017). World Population Prospects: The 2017 Revision, DVD Edition.

Vidal-Melia, C., Dominguez-Fabian, I., Devesa-Carpio, J. E. (2006). Subjective economic risk to beneficiaries in notional defined contribution accounts. Journal of Risk and Insurance, 73(3), 489-515. 
Wills, S., Sherris, M. (2010). Securitization, structuring and pricing of longevity risk. Insurance: Mathematics and Economics, 46(1), 173-185.

World Bank (1994). Averting the Old Age Crisis: Policies to Protect the Old and Promote Growth. World Bank Policy Research Report, 436 p.

Wrede, M. (1999). Pareto efficient pay-as-you-go pension systems with multi-period lives. Jahrbu"cher fur Nationalokonomie und Statistik, 219(3-4), 494-503. 


\section{Appendix 1}

Table 1. Ranges of Parameters in Target Functions of Pension Benefits and the Replacement Rate of the Pension System

\begin{tabular}{|c|c|c|c|c|c|c|}
\hline $\begin{array}{l}\text { Type of risk } \\
\text { impact }\end{array}$ & $\begin{array}{l}\text { Symbol } \\
\text { in the } \\
\text { formula }\end{array}$ & $\begin{array}{l}\text { Value of the } \\
\text { symbol }\end{array}$ & $\begin{array}{l}\text { Range of } \\
\text { coefficient } \\
\text { values }\end{array}$ & Note & $\begin{array}{l}\text { Values } \\
\text { for men }\end{array}$ & $\begin{array}{l}\text { Values } \\
\text { for } \\
\text { women }\end{array}$ \\
\hline \multirow{8}{*}{$\begin{array}{l}\text { Demographic } \\
\text { risks }\end{array}$} & $\mathrm{t}_{\mathrm{nj}}$ & $\begin{array}{l}\text { Period of pension } \\
\text { savings at present } \\
\text { (in years) }\end{array}$ & $\begin{array}{l}35.6(\text { men }) \\
130,6 \text { (women) }\end{array}$ & $\begin{array}{l}\text { Period of pension savings }= \\
\text { retirement age }(\mathrm{w}) .55 \text { for } \\
\text { women and } 60 \text { for men }- \text { the } \\
\text { age of starting working life }(\mathrm{v}) \\
(24.4 \text { as of } 2014)=35.6(\text { men }) / \\
30.6(\text { women })\end{array}$ & 35.6 & 30.6 \\
\hline & $\mathrm{t}_{\mathrm{ni}}$ & $\begin{array}{l}\text { Period of pension } \\
\text { savings in the } \\
\text { future (in years) }\end{array}$ & $\begin{array}{l}\text { [0; retirement } \\
\text { age }(\mathrm{w})-\text { age } \\
\text { of starting } \\
\text { working life } \\
\text { (v)] }\end{array}$ & $\begin{array}{l}\text { 1) Age of starting working life } \\
\text { (v) in } 2014 \text { was } 24.4 \text { years and } \\
\text { we assumed it as a constant in } \\
\text { our model } \\
\text { 2) Retirement age (w) - } \\
\text { variable (see The description } \\
\text { of the variables) }\end{array}$ & \multicolumn{2}{|c|}{ w- 24,4} \\
\hline & $\mathrm{t}_{\mathrm{vj}}$ & $\begin{array}{l}\text { Payment period } \\
\text { at present (in } \\
\text { years) }\end{array}$ & $\begin{array}{l}21.55 \text { (men) / } \\
24.56 \text { (women) } \\
\text { [the United } \\
\text { Nations data on } \\
\text { life expectancy } \\
\text { in 2014] }\end{array}$ & $\begin{array}{l}\text { Life age }(\mathrm{Li})=\text { const } \\
\text { [minimum on demographic } \\
\text { forecast; a maximum on } \\
\text { demographic forecast of the } \\
\text { United Nations (see } \\
\text { https://www.ssa.gov/oact/STA } \\
\text { TS/table4c6.html) }\end{array}$ & 21.55 & 24.56 \\
\hline & $\mathrm{t}_{\mathrm{vi}}$ & $\begin{array}{l}\text { Payment period } \\
\text { in future (in } \\
\text { years) }\end{array}$ & $\begin{array}{l}{[0 ; \text { life age }-} \\
\text { retirement } \\
\text { age- w] }\end{array}$ & $\begin{array}{l}\text { Payment period in future }=\text { life } \\
\text { expectancy for pensioners }(\mathrm{Lj} \text { ) } \\
\text { in future } 82.64 \text { (men) / } 85.65 \\
\text { (women) in the United } \\
\text { Nations (see } \\
\text { https://www.ssa.gov/oact/STA } \\
\text { TS/table4c6.html minus the } \\
\text { retirement age in future - } \\
\text { variable (see the description of } \\
\text { the variables) }\end{array}$ & $\begin{array}{c}{[82.64-} \\
w]\end{array}$ & $\begin{array}{c}{[85.65-} \\
w]\end{array}$ \\
\hline & $\mathrm{K}_{\mathrm{j}}$ & $\begin{array}{l}\text { The number of } \\
\text { working-age } \\
\text { population j year } \\
\text { at present as in } \\
2014 \text {, in million } \\
\text { people }\end{array}$ & $\begin{array}{l}86 \text { mln. people } \\
{[\text { SCS RF] }}\end{array}$ & $\begin{array}{l}\text { The number of working-age } \\
\text { population in year } \mathrm{j} \text { (at } \\
\text { present) as in } 2014\end{array}$ & \multicolumn{2}{|c|}{86} \\
\hline & $\mathrm{K}_{\mathrm{i}}$ & $\begin{array}{l}\text { The number of } \\
\text { working-age } \\
\text { population in } \\
\text { future (million } \\
\text { people) }\end{array}$ & $\begin{array}{l}{[73 ; 80]} \\
{[\text { SCS RF] }}\end{array}$ & $\begin{array}{l}\text { This can take any value in the } \\
\text { range from the pessimistic } \\
\text { forecast of the Russian SCS in } \\
2030 \text { to the optimistic forecast }\end{array}$ & \multicolumn{2}{|c|}{$[73 ; 80]$} \\
\hline & $\mathrm{n}_{\mathrm{j}}$ & $\begin{array}{l}\text { The number of } \\
\text { pensioners at } \\
\text { present (million } \\
\text { people) }\end{array}$ & 32 [SCS RF] & $\begin{array}{l}\text { The number of pensioners as } \\
\text { of } 2014\end{array}$ & \multicolumn{2}{|c|}{32} \\
\hline & $\mathrm{n}_{\mathrm{i}}$ & $\begin{array}{l}\text { The number of } \\
\text { pensioners in } \\
\text { future (million } \\
\text { people) }\end{array}$ & {$[36 ; 41]$} & $\begin{array}{l}\text { This can take any value in the } \\
\text { range from the pessimistic } \\
\text { forecast of the Russian SCS in } \\
2030 \text { to the optimistic forecast }\end{array}$ & {$[36 ; 41]$} & {$[36 ; 41]$} \\
\hline
\end{tabular}




\begin{tabular}{|c|c|c|c|c|c|}
\hline \multirow[b]{2}{*}{$\begin{array}{l}\text { Institutional } \\
\text { risks }\end{array}$} & $\mathrm{d}_{\mathrm{uz}}$ & $\begin{array}{l}\text { The share of } \\
\text { unearmarked } \\
\text { spendings PFR }\end{array}$ & \multirow{2}{*}{$\begin{array}{l}0.0247 \\
\text { [calculated by } \\
\text { the author on } \\
\text { the basis of } \\
\text { the budget of } \\
\text { PFR]* }\end{array}$} & \multirow{2}{*}{$\begin{array}{l}\text { This ratio is the amount of } \\
\text { pensions (all pensions except } \\
\text { insurance, funded and basic) to } \\
\text { the sum of the costs of PFR + } \\
\text { ratio of administrative expenses } \\
\text { to the sum of the costs of PFR } \\
\text { [Federal Law on Budget of the } \\
\text { Pension Fund of the Russian } \\
\text { Federation in 2014] }\end{array}$} & \multirow[b]{2}{*}{0.0247} \\
\hline & $\mathrm{d}_{\mathrm{lp}}$ & $\begin{array}{l}\text { The share of } \\
\text { pensions to } \\
\text { privileged } \\
\text { categories of } \\
\text { citizens of PFR }\end{array}$ & & & \\
\hline \multirow[t]{2}{*}{$\begin{array}{l}\text { Investment } \\
\text { risks }\end{array}$} & $\alpha$ & $\begin{array}{l}\text { Investment yields } \\
\text { at present } \\
\text { expressed as a } \\
\text { decimal }\end{array}$ & $\begin{array}{l}-0,004 \\
\text { [Official site of } \\
\text { the Ministry of } \\
\text { Finance } \\
\text { www.minfin.ru] }\end{array}$ & $\begin{array}{l}\text { The average yield of pension } \\
\text { investments in the period from } \\
2004 \text { to } 2014\end{array}$ & $-0,004$ \\
\hline & $\mathrm{PZ}_{\mathrm{j}}$ & $\begin{array}{l}\text { The replacement } \\
\text { rate of pensions } \\
\text { at present }\end{array}$ & $\begin{array}{l}0.34 \\
\text { [Official site } \\
\text { of the Pension } \\
\text { Fund RF } \\
\text { www.pfrf.ru] }\end{array}$ & $\begin{array}{l}\text { The replacement rate of } \\
\text { pensions as in } 2014 \text { [PFR] }\end{array}$ & 0.34 \\
\hline
\end{tabular}

*Note: Calculated by the authors according to the RPF in 2014 as the ratio of non-insurance costs (without insurance, funded and basic pensions) to total costs and forecast of the United Nations (see https://www.ssa.gov/oact/STATS/table4c6.html). 
Appendix 2

Abbreviations

ILO - the International Labour Organization

IRR - the internal rate of return

$\mathrm{RR}$ - the replacement rate

OLG Model - overlapping generations model

PAYG - Pay-as-you-go pension system is the unfunded pension system

VAR - the Value- at-Risk 